The professionals speak:

campaigning

\title{
Jens Tenscher
}

University of Trier, Germany

\section{Kar olina Koc-Michalska}

Audencia Business School, France

\section{Darren G Lilleker}

Bournemouth University, UK

\section{Juri Mykkänen}

University of Helsinki, Finland

\section{Annemarie S W alter}

University of Nottingham, UK

\author{
Andrej Findor \\ Comenius University in Bratislava, Sovakia
}

\section{Carlos Jalali}

University of Aveiro, Portugal

\section{Jlán Róka}

BKF University of Applied Sciences, Hungary

\begin{abstract}
Faced with some fundamental changes in the socio-cultural, political and media environment, political parties in post-industrialized democracies have started to initiate substantial transformations of both their organizational structures and communicative practices. Those innovations, described as professionalization, become most obvious during election campaigns. In recent times, the number of empirical studies measuring the degree of political parties' campaign professionalism has grown. They have relied on a broad spectrum of indicators derived from theory which have not been tested for their validity. For the first time, we put these indicators to a 'reality check' by asking top-ranked party secretaries and campaign managers in 12 European countries to offer their perceptions of professional election
\end{abstract}

Corresponding author:

Kar olina Koc-Michalska, Audencia Business School, 1 rue Marivaux, 44003 Nantes, France.

Email: kkocmichalska@sciencescom.org 
campaigning. Furthermore, we investigate whether any differences in understanding professionalism among party campaign practitioners can be explained by macro (country) and meso (party) factors. By and large, our results confirm the validity of most indicators applied in empirical studies on campaign professionalism so far. There are some party- and countryrelated differences in assessing campaign professionalism too, but the influence of most factors on practitioners' evaluations is weak. Therefore, we conclude that largely there is a far-reaching European Union-wide common understanding of professional election campaigning.

\section{Keywords}

Comparison, electoral campaigning, European Union, political parties, professionalism

\section{Introduction}

The literature on election campaigning has been dominated since at least the 1990s by the notion of professionalized campaigns (Asp and Esaiasson, 1996; Farrell, 1996; Farrell and Webb, 2000; Negrine et al., 2007; Norris, 2000; Scammell, 1995). The ubiquity of this notion was initially accompanied by a conceptual vagueness and a lack of empirical research that precluded a clear understanding of what constitutes professional campaigning (Lilleker and Negrine, 2002; Negrine and Lilleker, 2002). However, over the last decade, a set of broad characteristics of professional campaigning have been developed, specifically recognizing the homogenization of electioneering; the adaptation of corporate communication tools to the sphere of political campaigning; the centralization of strategic design; and the employment of consultants who have led to an embeddedness of core competences within party campaign organizations (e.g. Lisi, 2013).

Concurrently, intensive efforts have been made to develop theory-driven empirical indicators of these characteristics and to measure the degree of professionalization in campaigning (Gibson and Römmele, 2009; Moring et al., 2011; Strömbäck, 2009; Tenscher, 2013; Tenscher et al., 2012; Tenscher and Mykkänen, 2013). While (often slight) differences inevitably emerge between lists of indicators and methods of measurement, on the whole we can speak of a growing consolidation of our understanding of professionalized campaigns; how to measure these; and of what factors may explain inter-party and cross-national variation in the degree of professionalism in campaigning.

There is, however, one shortcoming in the existing empirical work on professionalized campaigning. By being based on either (meta) literature reviews or on researcher observation, it assesses how a professional campaign is expected or appears to operate. This article seeks to overcome this shortcoming, thus contributing to the consolidation of the empirical assessment of professionalized election campaigning. It does so by introducing a unique dataset by which to assess election campaign professionalism: the perceptions of party campaign practitioners from 68 parties across Europe. In particular, we are interested in understanding the following:

1. How practitioners understand and characterize professional election campaigns - and to what extent theoretically developed indicators of professional election campaigning are empirically valid.

2. To what extent there are differences between parties across nations in the understanding of professionalism and what explains these differences. 
By triangulating existing empirical work with the perceptions of campaign practitioners, this article allows us to further assess the validity of existing accounts of professionalism, with regard to: (1) what constitutes professional election campaigns and (2) what explains inter-party variation in professional campaigning. Our work will thus help corroborate prevailing notions of professionalized campaigning, and, where differences emerge between existing academic research and practitioners' perspectives, open new avenues for empirical research.

\section{The election campaign professionalism}

There is little doubt that the way electoral campaigns are planned, organized and conducted has changed profoundly over the last three decades. There is, however, less consensus on what has driven this change; how it has evolved over time and how it should be assessed. Initially, this change was considered to be part of fundamental processes of homogeneity such as ‘Americanization' or 'globalization' (Blumler and Gurevitch, 2001; Butler and Ranney, 1992; Farrell and Webb, 2000; Kavanagh, 1995; Plasser and Plasser, 2002; Scammell, 1995; Xifra, 2011). These terms point to a global export of campaign techniques and features that have been invented and primarily used in the United States. However, the extent of Americanization, as well as the validity of the assumptions underpinning this notion, has been extensively questioned. Studies have refuted the influence from US campaigns and specialist consultants who operate across nations, arguing that innovations emerge locally and simultaneous to developments in the United States. Only minimal evidence exists in direct replication (Baines and Egan, 2001; Holtz-Bacha, 2007; Negrine, 2008; Negrine and Papathanassopoulos, 1996). Although studies recognize some influence from practice in the United States, they acknowledge that the innovations are influenced by their local political, social and media environment (e.g. Uğur, 2012). Even consultants imported from the United States argue that local context matters (Lees-Marshment and Lilleker, 2012).

Setting the Americanization debate to one side, one cannot ignore the social, political and technological drivers within most post-industrial democracies that have shaped election campaigning. Since at least the beginning of the 1960s traditional class cleavages eroded and partisan dealignment delivered a more volatile electorate (Clarke et al., 2004). This electorate increasingly votes on the basis of personal economic calculations (Heath et al., 2001) and life style choices (Hooghe et al., 2002). As a result, parties have shifted from predominantly mobilizing adherents to persuading undecided voters at each contest. Furthermore, technological innovations have transformed the media environment, with multi-platform digital entertainment delivering a fragmented, hard to reach audience. The new media environment requires new campaign strategies and techniques. Cumulatively, these trends, affecting all developed nations, have led political parties to initiate substantial changes, both in their organizational structure and in their communicative strategy.

With regard to the evolution of campaigning, a number of influential works (Blumler and Kavanagh, 1999; Gibson and Römmele, 2001; Lees-Marshment, 2001; Norris, 2000: 137-147; Plasser and Plasser, 2002: 4-7) have characterized the transformation in campaigning into three ages or phases which are said to be different in their communicative modes, structures and strategies: a premodern (party and organization-centred), modern (candidate-centred) and postmodern (message- and 
marketing-driven) phase. While the phase model provides useful classification of how campaigning has generally changed over time, we should be careful not to rely on the model necessarily as a reflection of growing professionalization. Parties may use premodern, modern and postmodern techniques at the same time, according to specific contexts, needs and constraints. It is exactly this mixture of campaign components of different phases that characterize professional campaign management (Tenscher, 2007) as flexible adaptation.

Therefore, professionalized campaigning does not stand for a specific communication phase. To adapt the definition of Papathanassopoulos et al. (2007), a professionalized campaign is one that has a 'better and more efficient organization of resources and skills in order to achieve desired objectives' (p. 10). Professionalism in election campaigns thus reflects adaptations to modernization-related transformations in the campaign environment - notably in the political and media environment (Negrine and Lilleker, 2002) - and contains a number of structural and strategic components (Tenscher, 2007).

In recent years, there has been growing interest in measuring political parties' campaign professionalism (Gibson and Römmele, 2009; Lisi, 2013; Moring et al., 2011; Nord, 2006; Strömbäck, 2009; Tenscher et al., 2012) in first- and second-order elections and trends of professionalization (Tenscher, 2013; Tenscher and Mykkänen, 2013, 2014). Two main approaches can be identified in these measurements: (1) the CAMPROF-index introduced by Gibson and Römmele (2001), slightly adjusted by Strömbäck (2009), which concentrates on one dimension, that is, campaign structures (finances, personnel, infrastructure and communicative resources), and (2) the professionalization-index introduced by Tenscher (2007) and Tenscher et al. (2012) which differentiates between two dimensions: campaign structures and strategies.[AQ1] While campaign structures refer to organizational adaptations of political parties or their campaign 'hardware', campaign strategies incorporate a number of activities, such as event and news management, narrowcasting, personalization, free media or paid media activities, that is, a campaign's 'software' (Tenscher and Mykkänen, 2014: 7-9).

While these studies are valuable, the wider adequacy and validity of these measures need to be further tested. By presenting practitioners' perspectives on election campaign professionalism, we are able to further assess their validity. Using practitioners' perceptions to assess research findings is a growing practice across scientific domains (e.g. Ingram and Desombre, 1999; Rogers and Williams, 1989) and has shown considerable impact in political science also (viz., the reactions to Corbett, 2000). Moreover, as these practitioners play a key role in election campaign decisions, as such, their perceptions are likely to shape outcomes. And last but not least, practitioners have a unique vantage-point in election campaigns. Their perceptions provide insight into the dynamics of contemporary campaigning that are otherwise inaccessible. Overall, then, by assessing how these privileged observers of election campaigning perceive professionalism, we can more fully evaluate the academic constructs of professionalized campaigning, and gain insights into how campaigns are constructed and carried out. 
Table 1. Country characteristics (31 October 2013).

\begin{tabular}{|c|c|c|c|c|c|c|c|c|c|c|c|c|}
\hline & Austria & $\begin{array}{l}\text { Czech } \\
\text { Republic }\end{array}$ & Finland & France & Germany & Hungary & Malta & Netherlands & Portugal & Slovakia & Spain & United Kingdom \\
\hline $\begin{array}{l}\text { Political } \\
\text { system }\end{array}$ & $\begin{array}{l}\text { Semi-presidential } \\
\text { quasi- } \\
\text { parliamentary } \\
\text { democracy }\end{array}$ & $\begin{array}{l}\text { Parliamentary } \\
\text { democracy }\end{array}$ & $\begin{array}{l}\text { Parliamentary } \\
\text { democracy }\end{array}$ & $\begin{array}{l}\text { Semi- } \\
\text { presidential } \\
\text { parliamentary } \\
\text { democracy }\end{array}$ & $\begin{array}{l}\text { Parliamentary } \\
\text { democracy }\end{array}$ & $\begin{array}{l}\text { Parliamentary } \\
\text { democracy }\end{array}$ & $\begin{array}{l}\text { Parliamentary } \\
\text { democracy }\end{array}$ & $\begin{array}{l}\text { Parliamentary } \\
\text { monarchy/democracy }\end{array}$ & $\begin{array}{l}\text { Semi-presidential } \\
\text { quasi-parliamentary } \\
\text { democracy }\end{array}$ & $\begin{array}{l}\text { Parliamentary } \\
\text { democracy }\end{array}$ & $\begin{array}{l}\text { Parliamentary } \\
\text { monarchy/democracy }\end{array}$ & $\begin{array}{l}\text { Parliamentary } \\
\text { monarchy/democracy }\end{array}$ \\
\hline $\begin{array}{l}\text { First } \\
\text { democratic } \\
\text { election }\end{array}$ & 1945 & 1990 & 1907 & 1875 & 1949 & 1990 & 1966 & 1945 & 1975 & 1990 & 1977 & 1832 \\
\hline $\begin{array}{l}\text { Last } \\
\text { national } \\
\text { elections }\end{array}$ & 09/2013 & $10 / 2013$ & 03/2011 & $06 / 2012$ & 09/2013 & $05 / 2010$ & 03/2013 & 09/2012 & $06 / 2011$ & 03/2012 & $11 / 2011$ & 05/2010 \\
\hline $\begin{array}{l}\text { Electoral g } \\
\text { system }\end{array}$ & $\begin{array}{l}\text { Proportional } \\
\text { party list voting } \\
\text { with preferential } \\
\text { voting (electoral } \\
\text { numbers) }\end{array}$ & $\begin{array}{l}\text { Proportional } \\
\text { candidate/party } \\
\text { voting with } \\
\text { preferential } \\
\text { voting }\end{array}$ & $\begin{array}{l}\text { Proportional } \\
\text { candidate/party } \\
\text { voting }^{2}\end{array}$ & $\begin{array}{l}\text { First past the } \\
\text { post-candidate } \\
\text { voting in single } \\
\text { member } \\
\text { legislative } \\
\text { districts, two- } \\
\text { rounds system }\end{array}$ & $\begin{array}{l}\text { Proportional } \\
\text { candidate/party } \\
\text { voting }\end{array}$ & $\begin{array}{l}\text { Individual } \\
\text { constituency } \\
\text { seats; } \\
\text { combined } \\
\text { regional and } \\
\text { national party } \\
\text { lists }\end{array}$ & $\begin{array}{l}\text { Proportional } \\
\text { candidate } \\
\text { voting with } \\
\text { single } \\
\text { transfer able } \\
\text { votes }\end{array}$ & $\begin{array}{l}\text { Proportional party } \\
\text { list voting with } \\
\text { preferential voting }\end{array}$ & $\begin{array}{l}\text { Proportional party } \\
\text { voting, closed list }\end{array}$ & $\begin{array}{l}\text { Proportional } \\
\text { party voting } \\
\text { with } \\
\text { preferential } \\
\text { voting }\end{array}$ & $\begin{array}{l}\text { Proportional } \\
\text { candidate/party } \\
\text { voting }\end{array}$ & $\begin{array}{l}\text { First past the post- } \\
\text { candidate voting in } \\
\text { single member } \\
\text { legislative districts }\end{array}$ \\
\hline $\begin{array}{l}\text { Type of } \\
\text { government }\end{array}$ & Coalition & Coalition & Coalition & Coalition/block & Coalition/Block & Coalition & One party & Coalition & $\begin{array}{l}\text { Majoritarian/currently } \\
\text { a coalition }\end{array}$ & Coalition & Majoritarian & $\begin{array}{l}\text { Majoritarian/currently } \\
\text { a coalition }\end{array}$ \\
\hline $\begin{array}{l}\text { Number of } \\
\text { parties in } \\
\text { parliament }\end{array}$ & 6 & 7 & 9 & 9 & 5 & 4 & 2 & 11 & 5 & 7 & $7 / 16^{\mathrm{b}}$ & $10^{c}$ \\
\hline $\begin{array}{l}\text { Number of } \\
\text { parties } \\
\text { participating } \\
\text { in this study }\end{array}$ & 5 & 5 & 7 & 8 & 6 & 5 & 1 & 8 & 5 & 6 & 6 & 6 \\
\hline $\begin{array}{l}\text { Party } \\
\text { system }\end{array}$ & $\begin{array}{l}\text { Moderate } \\
\text { pluralistic }\end{array}$ & $\begin{array}{l}\text { Polarized } \\
\text { pluralistic }\end{array}$ & $\begin{array}{l}\text { Polarized to } \\
\text { moderate } \\
\text { pluralistic }\end{array}$ & $\begin{array}{l}\text { Moderate } \\
\text { pluralistic }\end{array}$ & $\begin{array}{l}\text { Moderate } \\
\text { pluralistic }\end{array}$ & $\begin{array}{l}\text { Polarized to } \\
\text { moderate } \\
\text { pluralistic }\end{array}$ & $\begin{array}{l}\text { Polarized } \\
\text { pluralist }\end{array}$ & Moderate pluralistic & $\begin{array}{l}\text { Moderate to } \\
\text { polarized pluralistic }\end{array}$ & $\begin{array}{l}\text { Moderate } \\
\text { pluralistic }\end{array}$ & $\begin{array}{l}\text { Moderate to } \\
\text { polarized pluralistic }\end{array}$ & Polarized pluralistic \\
\hline $\begin{array}{l}\text { Model of } \\
\text { media and } \\
\text { politics }\end{array}$ & $\begin{array}{l}\text { Democratic } \\
\text { corporatist }\end{array}$ & Transitory & $\begin{array}{l}\text { Democratic } \\
\text { corporatist }\end{array}$ & $\begin{array}{l}\text { Polarized } \\
\text { pluralist }\end{array}$ & $\begin{array}{l}\text { Democratic } \\
\text { corporatist }\end{array}$ & Transitory & $\begin{array}{l}\text { Polarized } \\
\text { pluralist }\end{array}$ & $\begin{array}{l}\text { Democratic } \\
\text { corporatist }\end{array}$ & Polarized pluralist & Transitory & Polarized pluralist & Liberal \\
\hline $\begin{array}{l}\text { Limitations } \\
\text { to electoral } \\
\text { expenses }\end{array}$ & Yes & No & Yes & Yes & No & Yes & Yes & No & Yes & No & Yes & Yes \\
\hline $\begin{array}{l}\text { Restrictions } \\
\text { on } \\
\text { advertising }\end{array}$ & Moderate & Moderate & None & Strict & Moderate & Moderate & Moderate & No & Moderate & Moderate & Moderate & Moderate \\
\hline
\end{tabular}

advertising

'There are seven parliamentary groups. O ne of them is called 'Plural Left' (composed of three parties that agreed to distribute territories where they were able to run) and another is called 'Mixed Group' with eight parties. 'Plus The Speaker and one Independent. 


\section{Methodology}

\section{case selection}

To acquire knowledge of practitioners' understanding of professional election campaigning, we conducted a survey among top-ranked party secretaries and campaign managers in 12 European countries. The countries selected reflect the broad spectrum of political, media- and campaign-related differences in contemporary Europe (Table 1). We expect that these contextual characteristics affect political actors' understanding of professional election campaigning (Plasser and Plasser, 2002; Tenscher et al., 2012).

First of all, the selected countries vary politically. Most of the selected countries are parliamentary democracies of which three have a monarchical tradition (Netherlands, Spain and United Kingdom). But the countries vary in democratic experience. While there have been parliamentary elections in France and the United Kingdom since the 19th century, in the new European Union (EU) member states, Czech Republic, Hungary and Slovakia, democracy was introduced no earlier than 1990. The countries also differ in their electoral systems: most of the countries examined operate a proportional representation electoral system in which either parties and/or candidates are elected. However, France and the United Kingdom use first past the post; in both countries, also candidates and not parties run for election.

Almost all countries have a coalition government, Malta being the exception. In addition, the party systems differ in the number of parties represented in parliament, from 2 (Malta) to 16 (Spain). In most of the countries, 5-10 parties are in parliament.

Second, the countries selected vary in their media environment, representing different 'models of media and politics' (Hallin and Mancini, 2004). Four belong to the Mediterranean, polarized pluralist model (France, Malta, Portugal and Spain) and four to the North/Central European, democratic corporatist model (Austria, Finland, Germany and Netherlands). Three countries were classified as 'transitory' (Tenscher, 2008) since their media systems are still under construction, respectively, the Czech Republic, Hungary and Slovakia. Finally, the North Atlantic or liberal model is represented by the United Kingdom.

Lastly, we selected the countries on their campaign regulations. We have chosen two discriminating indicators: limitations to electoral expenses and restrictions on advertising. While in eight countries electoral expenses are regulated by law, (almost) no limitations exist in the Czech Republic, Germany, the Netherlands and Slovakia. The Netherlands is the only country in our sample in which electoral campaign advertising is unrestricted. In most other countries, moderate regulations of the content, timing and/or extent of specific (not all) advertisements (e.g. TV commercials, billboards, posters and trinkets) exist. In France, all paid media activities are strictly controlled.

We included all parties that were represented in parliament and those parties that were, according to pre-election polls, expected to win at least one seat in the next election. In total, 82 parties were approached by the authors for an interview with topranked party secretaries, campaign managers or their equivalent (one person per party). Response rates varied from one party (Malta) to eight parties (France and Netherlands; Table 1). On average, $82.7 \%$ of those parties contacted participated $(S D=14.6)$. Our final sample consists of 68 parties. The interviews were conducted between February and September 2013 either face-to-face, by telephone or mail using a semistandardized questionnaire, which measured different aspects of professional campaigning in national parliamentary elections. 


\section{Operationalization}

To measure the validity and practical relevance of the indicators of professionalization developed from previous research, we made use of a set of closed questions. Respondents were asked to state how important each indicator is for a professional national parliamentary election campaign in their country. They could answer on a scale from 1 ('not at all important') to 5 ('very important'). ${ }^{1}$

In accordance with Tenscher (2007, 2013) and Tenscher et al. (2012), we initially separated structural or organization-related aspects of professional campaigning from strategic or communicative aspects. Organization-related aspects or campaigns' structural 'hardware' cover a number of features such as the size of the campaign budget, the staff size, campaign duration, the degree of centralization of campaign organization, the differentiation of internal communication structures, the degree of externalization, the nature and degree of feedback and the degree of opposition research. For theoretical reasons, these features were conceptualized as one dimension; empirically, the index of all indicators measuring the degree of campaigns' structural professionalism showed a sufficiently high internal consistency (e.g. Tenscher and Mykkänen, 2014: 10). For our study, we derived 12 items from this index: (1) a carefully planned budget, (2) the size of the campaign budget, (3) large number of employees in the national campaign headquarter, (4) clearly established roles and functions in the national campaign headquarters, (5) resources for opposition research, (6) centralized planning of the campaign by national headquarters, (7) centrally supervised campaign by national headquarters, (8) collaboration with experienced personnel from within the party, (9) collaboration with external consultants, (10) large number of campaign volunteers, (11) effective intra-party communication and (12) length of the campaign from the planning to Election Day.

In addition to organizational-related aspects, we asked the importance of elements of campaigns' 'software'. This includes the degree and relevance of news management, free media, talk shows and paid media, the degree of audience targeting, narrowcasting activities and personalization. In the studies mentioned above, these components seemed to build a distinct dimension separated from structural aspects (e.g. Tenscher, 2013: 247). We transformed the strategic indicators applied in Tenscher et al. (2012) into the following 32 items: (1) choice of right strategy, (2) negative campaigning, (3) willingness to attack the political opponent even 'below the belt', (4) clean (fair) campaigning, (5) choice of right issues, (6) the right top candidates, (7) willingness of the top candidates to reveal a little privacy, (8) good timing, (9) information on expectations and motivations of relevant groups of voters, (10) use of polls, (11) use of focus groups, (12) systematic observation of political opponents, (13) systematic press reviews and media content analyses, (14) having an impact on media's agenda, (15) use of paid media such as TV spots, posters or advertisements, (16) TV spots on public channels, (17) TV spots on commercial channels, (18) radio spots on commercial channels, (19) radio spots on public channels, (20) advertisements in print media, (21) Internet advertisements, (22) outdoor advertisements, (23) presence of party and top candidates on TV, (24) presence of party and top candidates on the Internet, (25) communication with voters via telephone, (26) email, (27) Facebook, (28) Twitter, (29) YouTube, (30) other online media, (31) face-to-face and (32) canvassing.

To answer the first research question (RQ1: To what extent are the indicators of professional campaigning discussed empirically adequate and valid?), we looked at the 
relevance of each item, on the basis of interviews and tested empirically the theoretically derived - dimensionality of the two main components, campaign structures and strategies, with factor analysis. This approach facilitates future empirical studies of professional election campaigning, as it provides a framework for weighing indicators properly (e.g. Tenscher et al., 2012: 165).

In the next step of analysis, we investigate the following research questions: (RQ2a) Are there party-related differences in understanding election campaign professionalism and (RQ2b) how can they be explained by (1) meso (party) and (2) macro (country) factors? In their original article on the party-centred theory of campaign professionalism, Gibson and Römmele (2001) outlined conditions that are likely to lead to the adoption of professional campaign techniques. Here, we follow their advice in operationalizing the key features they note when arguing, 'the move toward professional campaigning is seen as most likely to take place in a well-funded, mainstream, right-wing party with significant resources and a centralized internal power structure that has recently suffered a heavy electoral defeat and/or a loss of governing status' (Gibson and Römmele, 2001: 37). In addition, we assume that the length of parties' experience with democratic elections influences their understanding of professional campaigning, parties in new democracies being perhaps more prone to, for example, 'postmodern' campaign techniques. Although age of democracy is not straightforwardly a determinant of stability, it has been observed that party systems in new democracies show higher levels of electoral volatility and relative instability (Mainwaring and Zoco, 2007), which may have an effect on campaign structures and strategic decisions. Therefore, we have chosen the following independent variables at the meso-level:

Size (percentages of votes obtained at the last national parliamentary election); Party type (dichotomous variable differentiating catch-all and client parties depending on the share of votes); Ideology (a 5-point scale ranging from 1 'far left' to 5 'far right'); Internal shock (number of years since the last change in party leadership); External shock (electoral failure in previous national parliamentary election, measured as difference in percentage points gained in last elections compared to next to last elections); Parliamentary role (dummy variable differentiating between governmental, oppositional and extraparliamentary party); Electoral experience (years since party's foundation).

In this study, we are interested primarily in party-level effects due to a relatively small number of countries in our data. However, it is important to recognize that there are country- and region-specific patterns of election campaigning as well (Plasser et al., 1999; Plasser and Plasser, 2002; Tenscher et al., 2012) and thus, differences in these patterns should result in (or emerge from) diverse understandings of professional election campaigning. Country-related differences seem plausible in the light of a number of comparative studies dealing with the following: (1) first-order (e.g. Farrell, 2002; Norris, 2000) and second-order election campaigns in Europe (e.g. Bicchi et al., 2003; Tenscher et al., 2012); (2) variations in political consulting and political marketing (e.g. Lees-Marshment and Lilleker, 2012; Plasser and Plasser, 2002); (3) different approaches to web campaigning (e.g. Lilleker et al., 2011; Ward et al., 2008) and (4) with different types of national political communication cultures (Pfetsch, 2014). For these reasons, we included a number of country variables as controls in subsequent regressions models. These independent variables are prominent in the literature (e.g. Esser and Strömbäck, 2012; Hallin and Mancini, 2004; Swanson and Mancini, 1996): Size of the population; Turnout in the last parliamentary elections (measured in percentages); Interest in politics (4-point scale, recoded to 'strong' = 1 
Table 2. Evaluation of structural components of professional campaigning.

\begin{tabular}{|c|c|c|}
\hline & Mean & $\mathcal{D}$ \\
\hline A large number of campaign volunteers ${ }^{a}$ & 4.49 & .658 \\
\hline An effective intraparty communication ${ }^{a}$ & 4.44 & 699 \\
\hline Clearly established roles and functions in the national campaign headquarter ${ }^{a}$ & 4.40 & .883 \\
\hline A car efully planned budget ${ }^{\mathrm{a}}$ & 4.37 & .731 \\
\hline $\begin{array}{l}\text { A centralized planning of the campaign on the level of the national campaign } \\
\text { headquarter }^{a}\end{array}$ & 4.19 & 1.069 \\
\hline Collaboration with experienced personnel from within the party ${ }^{2}$ & 4.10 & .933 \\
\hline $\begin{array}{l}\text { A centrally supervised campaign from the level of the national campaign } \\
\text { headquarter }^{a}\end{array}$ & 3.96 & 1.112 \\
\hline The size of the campaign budget ${ }^{a}$ & 3.79 & .890 \\
\hline Length of the campaign from the planning to Bection Day ${ }^{a}$ & 3.53 & 1.085 \\
\hline Units/persons for opposition resear $\mathrm{ch}^{\mathrm{a}}$ & 3.50 & 1.072 \\
\hline A large number of employees in the national campaign headquarter & 2.94 & 1.035 \\
\hline Collaboration with external consultants & 2.94 & 1.244 \\
\hline Total & 3.51 & .523 \\
\hline
\end{tabular}

Scale: 1 ('not at all important') to 5 ('very important'), $N=68$.

Included in subsequent analyses.

and 'low' = 0, Source: Eurobarometer 78.1, November 2012); Trust in political parties (dichotomous variable differentiating between 'tend to trust' $=1$ and 'tend not to trust' $=0$, Source: Eurobarometer 78.1, November 2012); Degree of fragmentation of the parliamentary system (the degree of competition in the 'political market', measured as number of parties represented in the national parliament); Model of media and politics (dummy variable differentiating between liberal, democratic corporatist, polarized pluralist and transitory); Campaign regulations (i.e. limitations on electoral expenses and restrictions on advertising as dummy variables).

In this study, we test whether there are macro (national) explanations for differences rather than setting out macro-level hypotheses. Broadly, however, we might expect newer democracies to have adopted the latest techniques as much as possible, whereas older parties in older democracies may be more tied to traditional forms of campaigning. However, this may be mediated by the size of the population and fragmentation of the party system, both of which may demand greater professionalism. High or low levels of political interest or trust may have a variety of effects, demanding that specific strategies be pursued to a greater extent than others, as might the types of media system parties work within. Campaign regulation levels may act as constraints or facilitators, with our expectation being that the lower the regulations, the lower the professionalism as campaign strategy is free to use a broader range of 'software'. Our expectation is, however, that actually macro-level explanations will be weaker than meso-, party-level factors which are more likely significantly determine strategic thinking.

\section{Results}

Our first goal was to assess the adequacy and validity of the indicators of professional campaigning derived from the literature. Providing that a high degree of agreement exists between scholarly ideas and practitioners' views, we have confidence that these indicators are valid and reflect campaign reality across European parties. In Table 2, we present the means for the structural components of our measurement tool. 
For initial validation, we decided to drop all items failing to reach the 3.5 level of the 5-point scale. In other words, only those items that were deemed 'important' or 'very important' by the campaign managers were included in further analysis. Using this selection criterion, the collaboration with external consultants and having a large number of employees in party headquarters were dropped from the list of indicators of structural professionalism. It is worth noting that the least important structural features of campaigning are, besides external consultants and a large number of employees in the party headquarters, opposition research, a long campaign and a large budget. This finding contradicts to some extent the assessment of former campaign strategists emphasizing the extraordinary importance of large budgets for successful campaigning (e.g. Abrams, 1962: 4-5). Campaign managers nowadays seem to put more emphasis on division of labour, planning, communication and volunteers.

Examining whether there are significant differences between countries, we find that the only structural indicators that turned out statistically significant were those that measure the degree of campaign centralization, that is, central planning and central supervision. In most countries, centralization was considered important, however in France, Spain and United Kingdom the campaign managers were highly divided on this issue. In French and British parties, local autonomy was considered equally important to central coordination. This finding is unsurprising as France and the United Kingdom both have an electoral system with local voting in single member districts, and in the United Kingdom, there is a strong tradition of local campaigning at least in marginal constituencies (Negrine and Lilleker, 2002).

Considerably, more variance exists in the means of the strategic indicators (Table 3). Face-to-face communication with voters, visibility of the top candidates on television, issue choice and good strategy were almost unanimously considered 'very important' by the party representatives interviewed, whereas negative and unfair campaigning and use of private television and radio channels for airing spots were generally thought of as 'rather unimportant'. Out of the 32 indicators, 15 remained below the 3.5 level, yet only one indicator - unfair campaigning - had a lower value than 2. Yet, this indicator was not included in the original CAMPROF and professionalization indices. Almost all the removed indicators relate to the use of specific media for advertising purposes. Internet-based 'new media' appear also less relevant for the campaign managers (excluding Facebook). On the other hand, candidates' presence on the Internet and television is highly important as well as agenda control.

Large differences exist in the importance of these indicators at the country level, but it is not easy to recognize patterns. However, it is important to take up the issue of country differences here as a significant number of indicators were omitted due to them failing to meet the 3.5 or more average importance score. For example, negative campaigning, which was generally ranked least important, is seen as 'important' or 'very important' by the majority of French and Hungarian respondents. We are unable to explain this deviation. It might be the result of a national campaign culture more open to negative campaign techniques or resulting from the ideological polarization and personalization in Hungary during recent years. The importance of candidates' privacy was also exceptionally prominent among the Hungarian as well as Slovakian respondents. Hungary was the only country where the right choice of issues was also considered 'not important' by some party representatives. On the other hand, Hungary, Slovakia and the Czech Republic were the only countries in which the use of polls was 
Table 3. Evaluation of strategic components of professional campaigning.

\begin{tabular}{|c|c|c|}
\hline & Mean & $\mathscr{D}$ \\
\hline Choice of right strategy ${ }^{2}$ & 4.71 & .49 \\
\hline Choice of right issues $^{a}$ & 4.63 & .731 \\
\hline Presence of party and top candidates on $\mathrm{TV}^{\mathrm{a}}$ & 4.57 & .630 \\
\hline Communication with voters face-to-face ${ }^{a}$ & 4.57 & .816 \\
\hline Information on expectations and motivations of relevant groups of voters ${ }^{a}$ & 4.44 & .853 \\
\hline Good timing $^{a}$ & 4.4 & 672 \\
\hline An up-to-date appearance of party and top candidates on the Internet ${ }^{a}$ & 4.32 & .837 \\
\hline The right top candidates ${ }^{\mathrm{a}}$ & 4.26 & 1.141 \\
\hline Having an impact on media's agenda ${ }^{a}$ & 4.25 & .817 \\
\hline Communication with voters via Facebook $^{a}$ & 4.00 & .914 \\
\hline Systematic press reviews and media content analyses ${ }^{a}$ & 3.97 & .88 \\
\hline Canvassing $^{a}$ & 3.87 & 1.413 \\
\hline Systematic observation of political opponents ${ }^{a}$ & 3.81 & .996 \\
\hline Clean (fair) campaigning $^{a}$ & 3.78 & 1.104 \\
\hline Use of polls ${ }^{a}$ & 3.66 & 1.167 \\
\hline Use of focus groups ${ }^{a}$ & 3.57 & 1.163 \\
\hline Communication with voters via email $^{a}$ & 3.51 & 1.228 \\
\hline Communication with voters via YouTube & 3.46 & 1.043 \\
\hline Communication with voters via Twitter & 3.32 & 1.19 \\
\hline Use of outdoor advertisements & 3.28 & 1.610 \\
\hline Communication with voters via other 'new' media & 3.16 & 1.253 \\
\hline Use of Internet advertisements & 3.03 & 1.727 \\
\hline Use of advertisements in print media & 2.82 & 1.666 \\
\hline Use of radio spots on public channels & 2.76 & 1.527 \\
\hline Willingness of the top candidates to reveal a little privacy & 2.74 & 1.141 \\
\hline Use of TV spots on public channels & 2.69 & 1.605 \\
\hline Communication with voters via telephone & 2.69 & 1.273 \\
\hline Use of paid media such as TV spots, posters or advertisements & 2.68 & 1.966 \\
\hline Negative campaigning & 2.65 & 1.103 \\
\hline Use of radio spots on private channels & 2.56 & 1.661 \\
\hline Use of TV spots on private channels & 2.31 & 1.789 \\
\hline Willingness to eventually attack the political opponent even 'below the belt' & 1.90 & .979 \\
\hline Total & 3.89 & .494 \\
\hline
\end{tabular}

Scale: 1 ('not at all important') to 5 ('very important'), $N=68$.

ancluded in subsequent analyses.

considered 'important' or 'very important'. On the one hand, the results suggest that campaigning in 'new' democracies requires more emotionally laden, personalized and populist style in comparison to 'old' democracies. On the other, these findings might reflect a stronger 'Americanization', and so direct borrowing from established democracies, of campaign professionalism in Eastern Europe compared to Western Europe (Plasser, 2000: 45).

So far, we have merely eliminated index items that, in our rather conservative judgement, do not play an important role in electoral campaigns. Next, we assessed whether the - theoretically derived - dimensionality of the main components is supported empirically. We conducted a factor analysis separately for the structural and strategic aspects of the campaign. The number of factors present in the tables is a result of explorative iterations. No confirmatory analysis was performed. Initially, we assumed that the structural and strategic items would all load meaningfully on just one 
factor each. This produced very weak results. The next step was to find a statistically satisfactory solution which would also be meaningful in terms of interpretation. The results indicate clearly that we need to revise the unitary idea of organizing different campaign elements along two simple dimensions.

Table 4 shows three different factors for campaign structures. The first factor, which is statistically the most robust of the three, contains indicators that relate to organizational tasks of a campaign, such as planning, division of labour and collaboration. The second factor constitutes indicators of campaign resources if one is able to regard the length of the campaign as a campaign resource (the longer the campaign more resources are needed in general, but it does allow for more campaign activities). The third factor is less robust and has a relatively weak Cronbach's $\alpha$ value $(<.5)$. One could interpret this factor as comprising of features that relate to mobilizing (large number of volunteers) and coordinating (intra-party communication) the campaign. In this sense, the third factor bears affinity to the first, yet it has a wider focus and consequently contains features parties are more or less likely to include within their overall strategy as context demands as opposed to the use of each being contingent to some extent on one another.

In Table 5, the strategic indicators are divided between four factors. Each factor has at least a satisfactory Cronbach's $\alpha$ value which reflects internal factor coherence and thus we should be able to interpret these dimensions intuitively. The first factor combines voter information, timing, polling, focus groups and influencing the media agenda. Acquiring information about voters' expectations and motives, organizing polling and focus groups and influencing the media agenda indicate both adjusting campaign messages to the moods and preferences of the public and manipulating the public. The timing dimension is related to the latter function as the right moment to use information. Thus, the first factor covers strategic use of information. The second factor has a strong emphasis on campaign publicity; this time through the presence and selection of candidates as well as systematic follow-up activity by the campaign team. The third factor is oriented towards various ways of (electronically) contacting voters and sharing current information with them. Clean campaigning is hard-pressed to be included conceptually in this factor. However, it is logical if cleanness is viewed as part of the campaign image and regular communication with voters is associated with transparency. The fourth factor is difficult to interpret as it seems to split between personal contact with voters and campaign planning. Correspondingly, this factor has the lowest Cronbach's $\alpha$ value. In summary, campaign strategy can be divided into four dimensions: information, publicity, voter contact and the mixed factor that covers planning and personal presence in the field.

Second, we examined whether there are party-related differences in campaign professionalism (RQ2a). In Figure 1, all 68 parties in our sample are represented in a two-dimensional space consisting of our two basic indices of campaign professionalism. The points in the diagram are party means of the measures of campaign structures and strategies with a range of 1-5. We included only those variables that reached the cut-off point of 3.5 (Tables 2 and 3). Overall, it seems that strategic aspects are considered slightly more important by the campaign managers than structural aspects of a campaign. More than half of the parties are located on the left side of the diagonal axis, indicating emphasis on campaign strategy. Still, a strong correlation between evaluations of campaign structures and campaign strategy exists 
Table 4. Evaluations of structural components of professional campaigning.

\begin{tabular}{|c|c|c|c|}
\hline & \multicolumn{3}{|c|}{ Factor } \\
\hline & 1 & 2 & 3 \\
\hline Clearly established roles and functions in the national campaign headquarter & .737 & & \\
\hline $\begin{array}{l}\text { A centralized planning of the campaign on the level of the national campaign } \\
\text { headquarter }\end{array}$ & .840 & & \\
\hline $\begin{array}{l}\text { A centrally supervised campaign from the level of the national campaign } \\
\text { headquarter }\end{array}$ & .854 & & \\
\hline Collaboration with experienced personnel from within the party & .402 & & \\
\hline Units/persons for opposition research & .459 & & \\
\hline A car efully planned budget & & .578 & \\
\hline The size of the campaign budget & & .710 & \\
\hline Length of the campaign from the planning to Eection Day & & .764 & \\
\hline A large number of campaign volunteers & & & .748 \\
\hline An effective intraparty communication & & & .717 \\
\hline$\%$ of variance explained & 21.8 & 8.5 & 8.1 \\
\hline Cronbach's $\alpha$ & .719 & .518 & .468 \\
\hline
\end{tabular}

Principal component analysis; Varimax Rotation with Kaiser Normalization; factor values $>.30, N=68$.

Table 5. Analysis of evaluations of strategic components of professional campaigning.

\begin{tabular}{|c|c|c|c|c|}
\hline & \multicolumn{4}{|c|}{ Factor } \\
\hline & 1 & 2 & 3 & 4 \\
\hline $\begin{array}{l}\text { Information on expectations and motivations of relevant groups of } \\
\text { voters }\end{array}$ & .832 & & & \\
\hline Good timing & .477 & & & \\
\hline Having an impact on media's agenda & 679 & & & \\
\hline Use of polls & .776 & & & \\
\hline Use of focus groups & .638 & & & \\
\hline Presence of party and top candidates on TV & & .503 & & \\
\hline The right top candidates & & 613 & & \\
\hline Systematic press reviews and media content analyses & & .715 & & \\
\hline Systematic observation of political opponents & & .883 & & \\
\hline An up-to-date appearance of party and top candidates on the Interne & & & .766 & \\
\hline Communication with voters via Facebook & & & .792 & \\
\hline Clean (fair) campaigning & & & .414 & \\
\hline Communication with voters via email & & & .519 & \\
\hline Choice of right strategy & & & & .582 \\
\hline Choice of right issues & & & & .370 \\
\hline Communication with voters face-to-face & & & & .739 \\
\hline Canvassing & & & & .684 \\
\hline$\%$ of variance explained & 23.9 & 10.7 & 9.5 & 8.3 \\
\hline Cronbach's $\alpha$ & .766 & .714 & .520 & .450 \\
\hline
\end{tabular}

Principal component analysis; Varimax Rotation with Kaiser Nor malization; factor values $>.30, N=68$.

(Pearson's $r=.646, p \leq .01$ ). We also observe a considerable amount of variance within countries. For instance, the large UK parties (Labour and Conservatives in the lead) both appear highly professionalized, but the anti-EU United Kingdom Independence Party (UKIP) has the lowest scores of all parties involved in our study. 


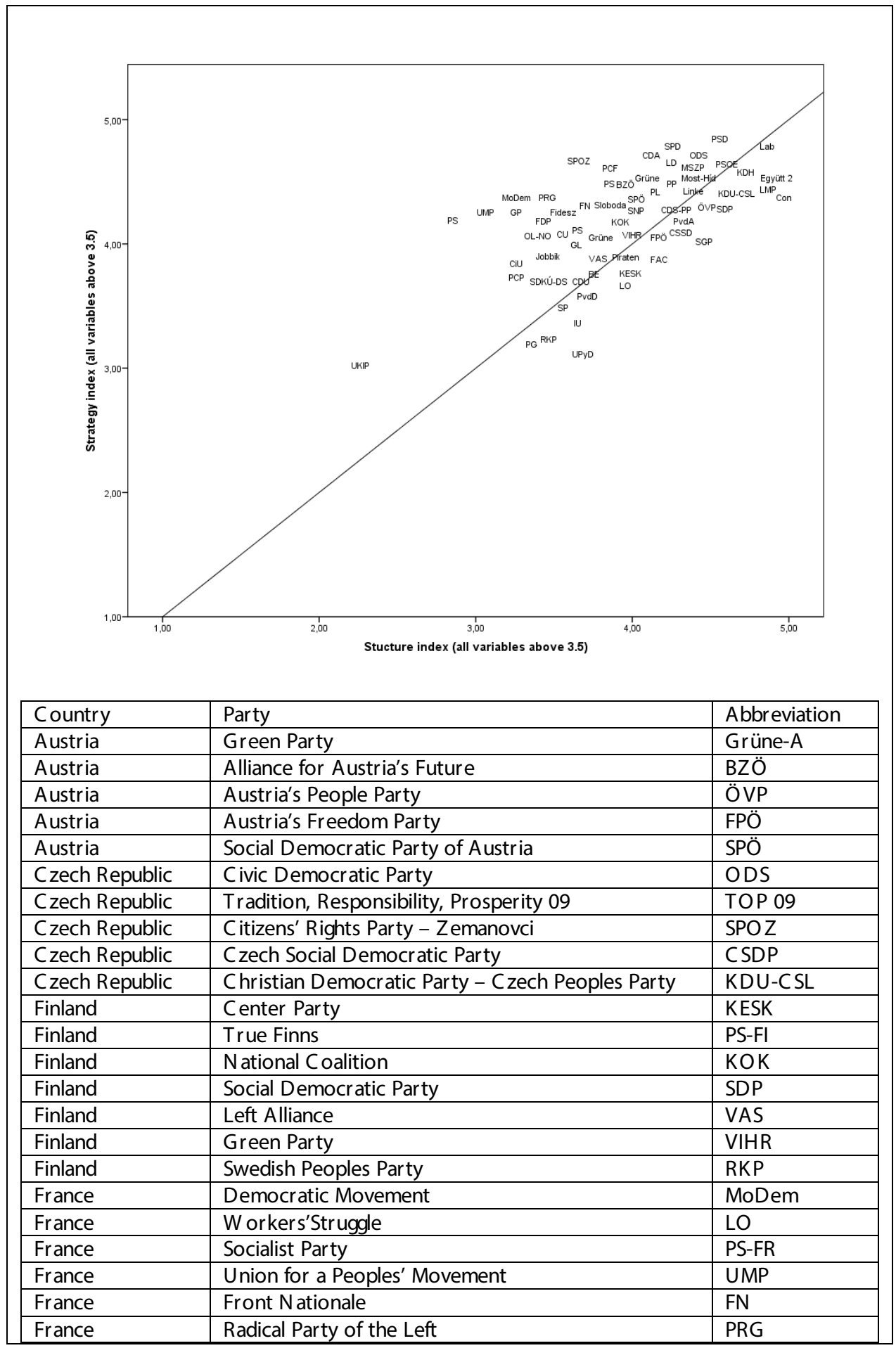




\begin{tabular}{|c|c|c|}
\hline France & French Communist Party & PCF \\
\hline France & The Left Party & PG \\
\hline Germany & Free Democratic Party & FDP \\
\hline Germany & Christian Democratic Union & CDU \\
\hline Germany & Leftist Party & Linke \\
\hline Germany & Green Party & Grüne-G \\
\hline Germany & Social Democratic Party & SDP \\
\hline Germany & Pirate Party & PP-G \\
\hline Hungary & $\begin{array}{l}\text { The Alliance for Young Democrats - Hungarian } \\
\text { Civic Party }\end{array}$ & Fidesz \\
\hline Hungary & Hungarian Socialist Party & MSZP \\
\hline Hungary & Movement for Better Hungary & Jobbik \\
\hline Hungary & Politics can be Different & LMP \\
\hline Hungary & Together 2014 & Együtt \\
\hline Malta & Labour Party & MLP \\
\hline Netherlands & Democrats 66 & D66 \\
\hline Netherlands & Christian Union & $\mathrm{CU}$ \\
\hline Netherlands & Animal Party & PvdD \\
\hline Netherlands & Labour Party & PvdA \\
\hline Netherlands & Orthodox Reformed Party & SGP \\
\hline Netherlands & Green Left & GL \\
\hline N etherlands & Socialist Party & $\mathrm{SP}$ \\
\hline Netherlands & Christian Democratic Appèl & CDA \\
\hline Portugal & Left Bloc & $\mathrm{BE}$ \\
\hline Portugal & Socialist Party & PS-PT \\
\hline Portugal & People's Party & PP-P \\
\hline Portugal & Social Democratic Party & PSD \\
\hline Portugal & Portuguese Communist Party & PCP \\
\hline Slovakia & Direction-Social Democracy & Smer-SD \\
\hline Slovakia & Christian-democratic Movement & $\mathrm{KDH}$ \\
\hline Slovakia & Ordinary people-Independent Personalities & OL'aNO \\
\hline Slovakia & Bridge & Most-Híd \\
\hline Slovakia & $\begin{array}{l}\text { Slovak Democratic and C hristian Union - } \\
\text { Democratic Union }\end{array}$ & SDKÚ-DS \\
\hline Slovakia & Freedom and Solidarity & SaS \\
\hline Spain & People's Party & PP-S \\
\hline Spain & Spanish Socialist W orkers Party & PSOE \\
\hline Spain & United Left & $\mathrm{IU}$ \\
\hline Spain & Union, Progress and Democracy & UPyD \\
\hline Spain & Convergence and Union & $\mathrm{CiU}$ \\
\hline Spain & The Asturias Forum-Regionalist Party & FAC \\
\hline United Kingdom & Liberal Democrats & LibDem \\
\hline United Kingdom & United Kingdom Independence Party & UKIP \\
\hline United Kingdom & Green Party & GP \\
\hline United Kingdom & Scottish National Party & SNP \\
\hline United Kingdom & Labour Party & $\mathrm{L}$ \\
\hline United Kingdom & Conservative Party & Con \\
\hline
\end{tabular}

Figure 1. Total evaluations of professional campaigning per party $(N=68)$. 
There is no single country whose parties would cluster in any one place in the figure. This strongly points towards studying party-level factors more carefully as country characteristics appear to explain few observed differences.

Finally, we explored the various dimensions of election campaign professionalism more fully in order to assess the explanatory power of country and party variables (RQ2b). Table 6 shows ordinary least squares (OLS) models for structural factors. As said earlier, we are mostly interested in meso- or party-level variables, whereas the macro- or country-level variables function here as controls. Although the models explain a relatively good amount of variance, none of the explanatory variables of primary interest were statistically significant, which is most likely due to the limited number of cases in our dataset. The first factor - which covers organizational aspects of campaigning - was associated with only one control variable, namely restrictions of advertising. The only explanation we might offer for this in the case of the first factor is that where advertising is restricted the most there are most likely less outside agencies involved and hence less strain on organization. Electoral experience comes out as the best explanation of the second factor (campaign resources). This seems logical as the parties that have functioned for a long time and experienced many elections have also developed organizational models for campaigning which, after being institutionalized, require resources. The third factor has no statistically significant correlations.

The OLS analyses of strategic factors are presented in Table 7. Our 'strategic use of information' Factor 1 correlates only with the catch-all type of party. Catch-all parties, by definition, try to appeal to heterogeneous audiences and maintain a wide political platform and may therefore have to resort to considerable planning of message distribution and group-specific moulding of message contents. For this purpose, the parties need information about voter preferences. Large parties are also more often subject to news coverage than smaller parties and they may have to pay more actively attention to their news management skills.

Concerning the second factor, only party size has a significant impact. We can assume that the larger the party (in terms of personnel and resources) the better opportunities there exist for presenting suitable top candidates for television, systematic campaign monitoring and analysing political opponents. Internal and external shocks come out as the best explanations of the third factor which deals with electronic communication with voters and fairness (or transparency). Net-based communication allows parties to manage their public image without interference by normal media gatekeepers and define their own sense of fair and open campaigning. This may become critically important when parties try to take the initiative after electoral defeat or change of party leadership. The fourth factor - which is internally divided between the substance of strategic choices and the importance of personal communication with voters - correlates with no party-level variables but with several country-level variables. The zero effect on party level is not surprising given the internal structure of the factor. On the macro-level, we see a few effects of interest. An interesting and relatively strong positive correlation is found between the factor and interest in politics. A highly engaged electorate may require more targeted and policy-specific communication and are more willing to discuss politics with candidates face-to-face. Success in previous election diminishes the importance of this factor which seems expected as success breeds self-confidence as well as less need for awareness building strategies. The importance of the factor decreases with increased public trust in parties 
Table 6. [AQ2] Explanations of evaluations of structural components of professional campaigning.

\begin{tabular}{|c|c|c|c|}
\hline & $\begin{array}{l}\text { Structural index: } \\
\text { Factor } 1\end{array}$ & $\begin{array}{l}\text { Structural index: } \\
\text { Factor } 2\end{array}$ & $\begin{array}{l}\text { Sructural index: } \\
\text { Factor } 3\end{array}$ \\
\hline \multicolumn{4}{|l|}{ Macro-level } \\
\hline Size of the population & .000 & .000 & .000 \\
\hline $\begin{array}{l}\text { Turnout in last parliamentary } \\
\text { election }\end{array}$ & -.061 & .036 & -.043 \\
\hline Interest in politics & 7.505 & -2.563 & 3.883 \\
\hline Trust in political parties & -.106 & .038 & -.052 \\
\hline $\begin{array}{l}\text { Fragmentation of the parliamentary } \\
\text { system }\end{array}$ & -.139 & .069 & -.078 \\
\hline $\begin{array}{l}\text { Model of media and politics: } \\
\text { democratic corporatist }\end{array}$ & -2.491 & .846 & -1.146 \\
\hline $\begin{array}{l}\text { Model of media and politics: } \\
\text { polarized pluralist }\end{array}$ & -.609 & .484 & -.280 \\
\hline $\begin{array}{l}\text { Model of media and politics: } \\
\text { transitory }\end{array}$ & -5.065 & 2.768 & -2.566 \\
\hline $\begin{array}{l}\text { Campaign regulations: limitations of } \\
\text { expenses }\end{array}$ & -.037 & .263 & .450 \\
\hline $\begin{array}{l}\text { C ampaign regulations: restricted } \\
\text { advertising }\end{array}$ & $-1.938^{*}$ & .484 & -1.054 \\
\hline \multicolumn{4}{|l|}{ Meso-level } \\
\hline Electoral experience & .003 & $.005^{* *}$ & .000 \\
\hline Size & .008 & -.006 & -.001 \\
\hline Party type (catch-all) & .161 & .100 & .062 \\
\hline Ideology & -.064 & -.027 & .005 \\
\hline Internal shock & -.011 & -.023 & -.007 \\
\hline External shock & -.005 & .010 & .011 \\
\hline Parliamentary role (governing) & .084 & .096 & .041 \\
\hline Constant & -4.905 & 5.190 & -.070 \\
\hline$R$ & .404 & .246 & .248 \\
\hline Adjusted $R$ & .179 & -.039 & -.036 \\
\hline
\end{tabular}

OLS linear regressions, $N=63$ (due to the fact of missing variables for the external shock variables (5)). ${ }^{*} p<.1 ;{ }^{* *} p<.05 ;{ }^{* * *} p<.01$.

Table 7. Explanations of evaluations of strategic components of professional campaigning.

\begin{tabular}{lllll}
\hline & \multicolumn{5}{l}{ Strategy index: Strategy index: Strategy index: Strategy index: } \\
& Factor 1 & Factor 2 & Factor 3 & Factor 4 \\
\hline Macro-level & & & & \\
\hline Size of the population & .000 & .000 & $.000^{*}$ & $.000^{* *}$ \\
Turnout in last parliamentary & -.024 & .026 & -.066 & $-.084^{* *}$ \\
$\quad \begin{array}{l}\text { election } \\
\text { Interest in politics }\end{array}$ & 4.346 & -4.635 & 8.366 & $13.557^{* *}$ \\
Trust in political parties & -.025 & .035 & $-.152^{*}$ & $-.212^{* *}$ \\
$\quad \begin{array}{l}\text { Fragmentation of the } \\
\text { parliamentary system }\end{array}$ & -.055 & .043 & $-.161^{*}$ & $-.268^{* * *}$ \\
$\quad \begin{array}{l}\text { Model of media and politics: } \\
\text { democratic corporatist }\end{array}$ & -1.866 & 2.306 & -2.864 & $-5.196^{* *}$ \\
Model of media and politics: & -.316 & .455 & -1.044 & $-1.711^{* *}$ \\
\hline
\end{tabular}




\begin{tabular}{|c|c|c|c|c|}
\hline \multicolumn{5}{|l|}{ polarized pluralist } \\
\hline $\begin{array}{l}\text { Model of media and politics: } \\
\text { transitory }\end{array}$ & -1.979 & 2.894 & -6.850 & $-9.937^{* *}$ \\
\hline & \multicolumn{3}{|c|}{ limitations of expenses } & .324 \\
\hline $\begin{array}{l}\text { Campaign regulations: restrictec } \\
\text { advertising }\end{array}$ & -1.027 & 1.241 & -1.185 & $-1.419^{*}$ \\
\hline \multicolumn{5}{|c|}{ Meso-level } \\
\hline Electoral experience & .003 & -.002 & -.003 & .003 \\
\hline Size & .007 & $.021^{*}$ & .006 & .001 \\
\hline Party type (catch-all) & $.486^{* *}$ & .179 & .266 & .182 \\
\hline Ideology & .032 & .007 & .045 & .015 \\
\hline Internal shock & -.024 & -.003 & $.053^{* *}$ & .001 \\
\hline External shock & -.002 & -.016 & $-.035^{* *}$ & -.011 \\
\hline Parliamentary role (governing) & .120 & -.203 & -.042 & -.067 \\
\hline Constant & -3.851 & 11.438 & -4.969 & $-12.871^{* *}$ \\
\hline$R$ & .461 & .247 & .252 & .495 \\
\hline Adjusted $\beta$ & .257 & -.037 & -.031 & .305 \\
\hline
\end{tabular}

OLS linear regressions, $N=63$ (due to the fact of missing variables for the external shock variables (5)). ${ }^{*} p<.1 ;{ }^{* *} p<.05 ;{ }^{* *} p<.01$.

and fragmentation of the party system. If people trust parties, the parties are perceived to have consistent programmes, and so there is less need for careful issue orientation and, perhaps, face-to-face campaigning. Party fragmentation is generally more prevalent in countries with a proportional system in which canvassing, for example, is less common than in majoritarian systems. Fragmented party systems will encourage quite specific issue orientation, to aid differentiation. Parties may find it more convenient to stick with their regular constituent interests. The macro variables are otherwise difficult to interpret as they tend to override each other's individual effect. This may be a result of multicollinearity but as we were interested in party variables this was not explored further.

\section{Conclusion and discussion}

This comparative study on the validity and adequacy of empirical indicators of professionalization of election campaigns has studied the perceptions of campaign experts of 68 political parties in 12 European countries (including several 'new' democracies). This study thereby presents a unique and very extensive dataset. Although this dataset is the largest to date, this study is still limited in scope, geographically and temporally. As a result, our statistical power $(N=68)$ is limited and all conclusions on the country (macro) and party (meso) factors explaining differences in campaign professionals' understandings of the concept of professionalization are exploratory and indicative only.

However, the study not only offers scholars greater knowledge on the validity of the tools they use to measure campaign professionalism, but also insights surrounding how these perceptions differ across countries and parties and indicates a basis for a theory on how these differences might be explained. In this study, we find that most of the indicators that were used in former studies to measure professional campaigning (e.g. Tenscher et al., 2012) were perceived as very important or important by campaign practitioners. However, there were also two structural components (a large number of employees in the national 
campaign headquarter and collaboration with external consultants) and 15 strategic items that did not make our cut-off point. As a consequence, we would argue that future studies measuring campaign professionalism should (1) cut down their list of indicators and (2) weigh indicators in accordance with the perceptions of campaign managers. This would bring theory of political campaigning closer to practice.

For the first time, we tested empirically the dimensionality of the two main components of professional campaigning, structures and strategies. Factor analysis showed that the campaign structure constitutes actually three components (i.e. campaign organization, resources and coordination) and that campaign strategy has four components (information, publicity, voter contact, and the mixed factor covering planning and personal presence in the field). Furthermore, the findings show us that there are some country differences in the perceptions of campaign professionalism and that on the strategic dimension these differences are also significant. Three country groups are found to record differences in the importance of the strategic elements of professional campaigning (low: France and Portugal; moderate: Finland, The Netherlands, Spain and UK; and high: Austria, Czech Republic, Germany, Hungary and Slovakia). Results indicate that explanatory factors for several components of the structural dimension of professional campaigning are electoral experience and campaign regulations on advertising. For the strategy dimension of professional campaigning factors, almost all hypothesized explanatory variables seem to matter.

A more pessimistic reading of these data is that the findings are somewhat random and may display weak or spurious causal relationships. As with all studies relying heavily on statistical analysis of a small number of cases, this may be a danger. We could therefore argue that there are minimal actual differences between the majority of parties surveyed, but there are outliers which skew findings. Such a conclusion may indicate equalization in terms of professionalization (Plasser, 2000), with parties campaigning using fairly similar strategies just reporting slightly different priorities. Here, we argue that other less tangible variables are at play such as party traditions of campaigning and perceptions of what works within their context. Equally, parties may feel certain methods of reaching and influencing voters are more appropriate given their character, ethos, identity or the demographic they see as most fertile to target. Such indicators may in some cases be governed by resources but could also be a feature of other decision-making processes internal to the party.

While we are aware of the limitations of this study in its sample size, we think it is a step forward towards a more complete theory on campaign professionalization and a better tool to measure professionalism in campaigning, one that is not only useful in the eyes of scholars studying election campaigns, but also for campaign practitioners.

Further research is needed studying perceptions of professional campaigning over an even larger number of countries, parties and elections to strengthen the preliminary claims made and conclusions drawn in this study. In particular, research across the EU28 nations, possibly including a wider sample of political parties in order to increase the suitability of the sample size for regression analysis. Confirmatory interviews could also be carried out within parties to ensure the validity of the perceptions of practitioners. Of greatest importance though is testing the factor analysis and validity of the structural and strategic component groupings. Further testing is also required of the key findings to determine the validity of the explanatory variables or indeed whether inter-party and cross-national differences are actually minimal and we are largely finding homogeneity in campaign professionalism. 


\section{Acknowledgements[AQ3]}

This article is dedicated to the memory of Jens Tenscher (1969-2015), friend and colleague, who made this research possible. We want to thank María José Canel (Complutense University of Madrid), Olga Gyarfasova (Comenius University), Tom Moring (University of Helsinki), Rui Dias Oliveira (University of Aveiro), Carmen Sammut (University of Malta), Václav Štětka (Charles University in Prague) and Philip van Praag (University of Amsterdam) for their participation and permission to use their countries' data. We would also like to thank Isabelle Veyrat-Masson and Pierre Lefebure (Le Laboratoire Communication et Politique) for data collection in France.

\section{Funding}

The author(s) received no financial support for the research, authorship and/or publication of this article.

\section{Note}

1. Missing values were set to 0 .

\section{References}

Abrams M (1962) Professionalism in politics. Socialist Commentary: 3-5.[AQ4]

Asp K and Esaiasson P (1996) The modernization of Swedish campaigns: Individualization, professionalization, and medialization. In: Swanson DL and Mancini P (eds) Politics, Media, and Modern Democracy: An International Study of Innovations in Electoral Campaigning and Their Consequences. Westport, CT: Praeger, pp. 73-90.

Baines PR and Egan J (2001) Marketing and political campaigning: Mutually exclusive or exclusively mutual? Qualitative Market Research 4(1): 25-34.

Bicchi F, Jean B and Palle S (2003) The European parliament campaign. Working paper, European University Institute, Florence.

Blumler JG and Gurevitch M (2001) Americanization reconsidered: UK-US campaign communication comparisons across time. In: Bennett L and Entman R (eds) Mediated Politics: Communication in the Future of Democracy. Cambridge: Cambridge University Press, pp. 380-404.

Blumler JG and Kavanagh D (1999) The third age of political communication: Influences and features. Political Communication 16(3): 209-230.

Butler D and Austin R (eds) (1992) Electioneering: A Comparative Study of Continuity and Change. Oxford: Clarendon Press.

Clarke HD, Sanders D, Marianne C, et al. (2004) Political Choice in Britain. Oxford: Oxford University Press.

Corbett R (2000) Academic modelling of the codecision procedure: A practitioner's puzzled reaction. European Union Politics 1(3): 373-381.

Esser F and Strömbäck J (2012) Comparing election campaign communication. In: Esser F and Hanitzsch T (eds) The Handbook of Comparative Communication Research. New York: Routledge, pp. 289-307.

Farrell DM (1996) Campaign strategies and tactics. In: LeDuc L, Niemi RG and Norris P (eds) Comparing Democracies: Elections and Voting in Global Perspective. London: SAGE.[AQ5]

Farrell DM (2002) Campaign modernization and West European party. In: Luther KR and Müller-Rommel F (eds) Political Parties in the New Europe: Political and Analytical Challenges. London: Routledge, pp. 63-84. 
Farrell DM and Webb P (2000) Political parties as campaign organizations. In: Dalton RJ and Wattenberg MP (eds) Parties without Partisans. Oxford: Oxford University Press, pp. 102-125.

Gibson R and Römmele A (2001) A party-centered theory of professionalized campaigning. The Harvard International Journal of Press/Politics 6(4): 31-43.

Gibson R and Römmele A (2009) Measuring the professionalization of political campaigning. Party Politics 15(3): 321-339.

Green DP and Smith JK (2003) Professionalization of campaigns and the secret history of collective action problems. Journal of Theoretical Politics 15(3): 321-339.[AQ6]

Hallin DC and Paolo M (2004) Comparing Media Systems: Three Models of Media and Politics. Cambridge: Cambridge University Press.

Heath AF, Jowel RM and Curtice JK (2001) The Rise of New Labour: Party Policies and Voter Choices. Oxford: Oxford University Press.

Holtz-Bacha C (2007) Professionalisation of politics in Germany. In: Negrine R, Mancini P, Holtz-Bacha C, et al. (eds) The Professionalization of Political Communication. Bristol and Chicago, IL: Intellect, pp. 63-79.

Hooghe L, Gary M, Carole J, et al. (2002) Does left/right structure party positions on European integration? Comparative Political Studies. 35(8): 965-989.

Ingram $\mathrm{H}$ and Desombre $\mathrm{T}$ (1999) Teamwork: Comparing academic and practitioners' perceptions. Team Performance Management 5(1): 16-22.

Kavanagh D (1995) Election Campaigning: The New Marketing of Politics. Oxford: Wiley-Blackwell. Lees-Marshment J (2001) The marriage of politics and marketing. Political Studies 49(4): 692-713.

Lees-Marshment J and Lilleker DG (2012) Knowledge sharing and lesson learning: Consultants perspectives on the international sharing of political marketing strategy. Contemporary Politics 18(3): 343-354.

Lilleker DG and Lees-Marshment J (eds) (2005) Political Marketing: A Comparative Perspective. Manchester: Manchester University Press.

Lilleker DG and Negrine R (2002) Professionalization: Of what? Since when? By whom? The Harvard International Journal of Press/Politics 7(4): 98-103.

Lilleker DG, Koc-Michalska K, Schweitzer EJ, et al. (2011) Informing, engaging, mobilizing or interacting: Searching for a European model of web campaigning. European Journal of Communication 26(3): 195-213.

Lisi M (2013) The professionalization of campaigns in recent democracies: The Portuguese case. European Journal of Communication 28(3): 259-276.

Maarek PJ (2011) Campaign Communication and Political Marketing. Chichester: WileyBlackwell.[AQ7]

Mainwaring S and Zoco E (2007) Political sequences and the stabilization of interparty competition: Electoral volatility in old and new democracies. Party Politics 13(2): 155-178.

Mancini P (1999) New frontiers in political professionalism. Political Communication 16(3): 231-245.[AQ8]

Moring T, Mykkänen J, Nord L, et al. (2011) Campaign professionalization and political structures: A comparative study of election campaigning in Finland and Sweden in the 2009 EP Elections. In: Maier M, Strömbäck J and Kaid LL (eds) European Political Communication: Campaign Strategies, Media Coverage, and Campaign Effects in European Parliamentary Elections. Farnham: Ashgate, pp. 45-60.

Negrine R (2008) The Transformation of Political Communication. Basingstoke: Palgrave Macmillan.

Negrine R and Lilleker DG (2002) The professionalization of political communication: Continuities and change in media practices. European Journal of Communication 17(3): 305-323.

Negrine R and Papathanassopoulos S (1996) The 'Americanization' of political communication'. The International Journal of Press/Politics 1(2): 45-62. 
Negrine R, Mancini P, Holtz-Bacha C, et al. (eds) (2007) The Professionalization of Political Communication. Bristol and Chicago, IL: Intellect.

Nord L (2006) Still the middle way: A study of political communication practices in Swedish election campaigns. The Harvard International Journal of Press/Politics 11(1): 64-76.

Norris P (2000) A virtuous circle: Political communications in postindustrial societies. Cambridge: Cambridge University Press.

Papathanassopoulos S, Negrine R, Mancini P, et al. (2007) Political communication in the era of professionalisation. In: Negrine R, Mancini P, Holtz-Bacha C, et al. (eds) The Professionalization of Political Communication. Bristol and Chicago, IL: Intellect, pp. 9-25.

Pfetsch B (ed.) (2014) Political Communication Culture in Western Europe: Attitudes of Political Actors and Journalists in Nine Countries. Houndmills: Palgrave Macmillan.

Plasser F (2000) American campaign techniques worldwide. The Harvard International Journal of Press/Politics 5(4): 33-54.

Plasser F and Plasser G (2002) Global Political Campaigning: A Worldwide Analysis of Campaign Professionals and Their Practices. Westport, CT and London: Praeger.

Plasser F, Christian S and Christian S (1999) Is there a European style of political marketing? A survey of political managers and consultants. In: Newman BE (ed.) Handbook of Political Marketing. Thousand Oaks, CA: SAGE, pp. 89-112.

Rogers JC and Williams TG (1989) Comparative advertising effectiveness: Practitioners' perceptions versus academic research findings. Journal of Advertising Research 29(3): 22-36.

Scammell M (1995) Designer Politics: How Elections are Won. London: Palgrave Macmillan.

Strömbäck J (2009) Selective professionalisation of political campaigning: A test of the partycentered theory of professionalised campaigning in the context of the 2006 Swedish election. Political Studies 57(1): 95-116.

Swanson DL and Mancini P (eds) (1996) Politics, Media, and Modern Democracy: An International Study of Innovations in Electoral Campaigning and Their Consequences. Westport: Praeger.

Tenscher J (2007) Professionalisierung nach Wahl: Ein Vergleich der Parteienkampagnen im Rahmen der jüngsten Bundestags- und Europawahlkämpfe in Deutschland. In: Brettschneider F, Niedermayer O and Weßels B (eds) Die Bundestagswahl 2005: Analysen des Wahlkampfes und der Wahlergebnisse. Wiesbaden: Springer VS, pp. 65-95.[AQ9]

Tenscher J (2008) Massenmedien und politische Kommunikation in den Ländern der Europäischen Union. In: Gabriel OW and Kropp S (eds) Die EU-Staaten im Vergleich: Strukturen, Prozesse, Politikinhalte. Wiesbaden: Springer VS, pp. 412-447. [AQ10]

Tenscher J (2013) First- and second-order campaigning: Evidence from Germany. European Journal of Communication 28(3): 241-258.

Tenscher J and Mykkänen J (2013) Transformations in second-order campaigning: A GermanFinnish comparison of campaign professionalism in the European parliamentary elections 2004 and 2009. Central European Journal of Communication 6(2): 171-187.

Tenscher J and Mykkänen J (2014) Two levels of campaigning: An empirical test of the partycentred theory of professionalisation. Political Studies 62: 20-41.

Tenscher J, Mykkänen J and Moring T (2012) Modes of professional campaigning: A fourcountry-comparison in the European parliamentary elections 2009. The International Journal of Press/Politics 17(2): 145-168.

Uğur G (2012) Americanisation of political communication. Canadian Social Science 8(3): 1-7.

Ward S, Owen D, Davis R, et al. (eds) (2008) Making a Difference: A Comparative View of the Role of the Internet in Election Politics. Lanham, MD: Lexington Books.

Xifra J (2011) Americanization, globalization, or modernization of electoral campaigns? Testing the situation in Spain. American Behavioral Scientist 55(6): 667-682. 